\title{
Analisis Fitokimia dan Aktivitas Antioksidan Ekstrak Daun Kesambi (Schleichera oleosa) Metode DPPH
}

\author{
Kholifah Holil ${ }^{1}$, Tias Pramesti Griana ${ }^{2 *}$ \\ ${ }^{1}$ Jurusan Biologi, Fakultas Sains dan Teknologi, UIN Maulana Malik Ibrahim Malang, Indonesia \\ ${ }^{2}$ Program Studi Pendidikan Dokter, Fakultas Kedokteran dan Ilmu Kesehatan, UIN Maulana Malik Ibrahim Malang, Indonesia \\ *E-mail: tiaspram_esti@yahoo.co.id
}

\begin{abstract}
Kesambi (Schleichera oleosa) is one of the forest plants from Indonesia that has potential as medicine. Kesambi has active compounds that act as antioxidants. The purpose of this study was to determine the potential of kesambi leaf as an antioxidant using the DPPH method. Samples of kesambi leaf were extracted in methanol, ethanol, and water solvents by the maceration method. The class of compounds contained in kesambi leaf was tested by the colour reaction test method for alkaloids, flavonoids, triterpenoids, phenols, steroids, saponins, and tannins. Antioxidant activity was tested by the DPPH method to determine IC50 values. Based on the results of the colour reaction test showed that methanol and ethanol solvents were able to bind 6 classes of compounds (alkaloids, flavonoids, triterpenoid, phenols, saponins, and tannins) and water solvents were only able to bind 5 classes of compounds (flavonoids, triterpenoid, phenols, saponins, and tannins) contained in kesambi leaf. The results of antioxidant activity tests using the DPPH method showed the lowest IC50 value was methanol extract $(16,12 \mu \mathrm{g} / \mathrm{ml})$ compared to ethanol extract $(20,43 \mu \mathrm{g} / \mathrm{ml})$ and water $(904,28 \mu \mathrm{g} / \mathrm{ml})$. It was concluded that the leaf extract of kesambi has potential as an antioxidant and which has the best antioxidant ability was extracted in methanol. The class of compounds which were thought to be responsible for the antioxidant activity of the kesambi leaf extract based on the color reaction test were phenols, flavonoids and tannins.
\end{abstract}

Keywords: antioxidant, kesambi, Schleichera oleosa, DPPH

\section{ABSTRAK}

Kesambi (Schleichera oleosa) merupakan salah satu tanaman hutan asli Indonesia yang berpotensi sebagai obat. Kesambi memiliki senyawa aktif yang berperan sebagai antioksidan. Tujuan dari penelitian ini adalah untuk mengetahui potensi daun kesambi sebagai antioksidan menggunakan metode DPPH. Simplisia daun kesambi di ekstraksi dalam pelarut metanol, etanol dan air dengan metode maserasi. Golongan senyawa kimia yang terkandung didalam esktrak daun kesambi di analisa dengan uji reaksi warna untuk golongan alkaloid, flavonoid, triterpenoid, fenol, steroid, saponin, dan tanin. Aktivitas antioksidan di uji dengan DPPH untuk diketahui nilai IC50. Berdasarkan hasil uji reaksi warna menunjukkan pelarut metanol dan etanol mampu mengikat 6 golongan senyawa (alkaloid, flavonoid, triterpenoid, fenol, saponin, dan tanin) dan pelarut air hanya mampu mengikat 5 golongan senyawa (flavonoid, triterpenoid, fenol, saponin, dan tanin). Hasil uji aktivitas antioksidan dengan menggunakan metode DPPH menunjukkan nilai IC50 ekstrak metanol adalah paling rendah $(16,12 \mu \mathrm{g} / \mathrm{mL})$ dibandingkan dengan ektrak etanol $(20,43 \mu \mathrm{g} / \mathrm{mL})$ dan air $(904,28 \mu \mathrm{g} / \mathrm{mL})$. Disimpulkan bahwa ekstrak daun kesambi berpotensi sebagai antioksidan dan yang memiliki kemampuan antioksidan paling baik adalah yang menggunakan ektrak dengan pelarut metanol. Golongan senyawa yang diduga bertanggungjawab terhadap aktivitas antioksidan ekstrak daun kesambi berdasarkan uji reaksi warna adalah fenol, flavonoid dan tanin. 


\section{Pendahuluan}

Kesambi (Schleichera oleosa (L.) Oken.) merupakan tanaman pohon hutan tropis salah satu dari famili Sapindaceae yang tersebar di wilayah Asia Selatan dan Asia Tenggara (Kamboja, India, Indonesia, Myanmar, Sri Langka, Thailand dan Vietnam) [1]. Tanaman kesambi dikenal juga dengan nama daerah : kasambi (Sunda); kesambi, kusambi, sambi (Jawa dan Bali); kasambhi (Madura); kusambi, usapi (Timor Timur); kasembi, kahembi (Sumba); kehabe (Sawu); kabahi (Solor); kalabai (Alor); kule, ule (Rote); bado (Makasar); ading (Bugis) [2].

Pemanfaatan kesambi sudah dikenal sejak dulu. Dibidang pertanian dan peternakan, kulit biji kesambi dimanfaatkan sebagai pupuk tanaman jagung dan daunnya sebagai pakan ternak [3]. Dibidang industri, minyak dari buah kesambi dapat digunakan sebagai sumber biodiesel [4], sedangkan pohon kesambi berperan sebagai inang kutu lak yang mempunyai nilai ekonomis tinggi, dimana lak adalah bahan dasar untuk pembuatan isolasi listrik, piringan hitam, tinta cetak, ampelas, semir, kapsul obat, pelitur dan cat [3]. Di bidang pengobatan tradisional, dikenal sebagai Macassar oil untuk pelembut rambut, menyembuhkan penyakit gatal, eksim, kudis, koreng, dan jerawat. Bubuk biji kesambi digunakan sebagai obat luka pada ternak dan daunnya dapat mengobati penyakit malaria [2].

Kulit batang kesambi mengandung senyawa fenolik [5] yang terdiri dari 1,2-Benzenedicarboxylic acid, diisooctyl ester dan squalene [6]. Buah kesambi mengandung senyawa fenolik yang terdiri dari protocatechuic acid, p-hydroxy benzoic acid, vanillic acid, caffeic acid, syringic acid dan $p$ coumaric acid [7]. Kulit buah dan biji kesambi mengandung saponin, alkaloid, terpenoid, flavonoid dan tanin [8,9]. Daun kesambi mengandung metabolit sekunder yang berupa alkaloid, fenolik, tanin, dan flavonoid. Fenolik dan flavonoid merupakan komponen terbanyak pada daun kesambi, dan hasil analisa dengan metode thin layer chromatography (TLC) didapatkan quercetin sebagai salah satu komponen flavonoid dalam daun kesambi [10]. Telah diketahui berbagai tanaman yang mengadung senyawa fenolik dan flavonoid memiliki kemampuan sebagai antioksidan dengan metode DPPH $[11,12]$.

Pelarut yang digunakan untuk ekstraksi senyawa metabolit dari tanaman dipilih berdasarkan polaritas zat terlarut. Suatu pelarut dengan polaritas yang mirip dengan zat terlarut akan melarutkan zat terlarut dengan baik [13]. Senyawa metabolit didalam tanaman ada pada dinding sel, vakuola dan inti sel [14]. Pelarut dengan polaritas yang rendah tidak akan dapat mengikat senyawa metabolit didalam sel pada sampel kering (simplisia) [15]. Berdasarkan indeks polaritas, metanol, etanol dan air memiliki indeks polaritas yang tinggi, dimana nilai indeks polaritas metanol 5,1, etanol 5,2 dan air 9 [16] sehingga metanol, etanol dan air lebih banyak dipilih untuk ekstraksi tanaman obat yang mengandung senyawa metabolit. Penelitian ini bertujuan untuk mengetahui potensi daun Schleichera oleosa sebagai antioksidan. Pelarut untuk mengekstraksi daun kesambi yang digunakan dalam penelitian ini adalah metanol $90 \%$, etanol $96 \%$ dan air.

\section{Bahan dan Metode}

\subsection{Bahan tanaman dan bahan kimia}

Simplisia daun kesambi didapat dari UPT Materia Medica, kota Batu dengan kunci determinasi : 1b-2b-3b-4b-6b-7b-9b10b-11b-12b-13b-14a-15b-197b-208b-219b-220a-221b-

$222 a-1 b-5 b-6$.

Bahan kimia dalam penelitian ini terdiri dari: Metanol 90\% (grade Pro Analysis, Merck, German), etanol 96\% (grade Pro Analysis, Merck, German), ammonia (CHCl3) 0,05N (Ricca, USA), asam sulfat (H2SO4) 2N (Ricca, USA), ferriklorida (FeCl3) 0,1\% (Ricca, USA), regen Meyer (Sigma Aldrich, German), regen Bouchardat (Ricca, USA), regen Dragendorff (Merck, German), regen DPPH (Sigma Aldrich, German), asam askorbat (Merck, German).

\subsection{Metode ekstraksi}

Serbuk simplisia dimaserasi dengan merendam di pelarut aquades, etanol $96 \%$ dan metanol $90 \%$ dengan perbandingan simplisia : pelarut $=1: 5$ selama 24 jam. Dimasukkan larutan simplisia ke dalam incubator shaker dengan kecepatan $125 \mathrm{rpm}$ suhu $37^{\circ} \mathrm{C}$ selama 3 jam. Disaring dengan kertas saring dan ampas yang diperoleh dimaserasi kembali dengan pelarut yang sama dan diulang 3 kali. Filtrat di evaporasi dengan rotary evaporator dengan suhu $60^{\circ}$ dan tekanan 0,045mPA selama 30 menit.

\subsection{Uji reaksi warna (flavonoid, alkaloid, tanin, terpenoid, fenol, dan saponin)}

Dimasukkan $2 \mathrm{~g}$ ekstrak ke dalam beaker glass dan ditambahkan $20 \mathrm{~mL}$ aquades, kemudian dididihkan lalu disaring. Dimasukkan $0,5 \mathrm{~mL}$ filtrat kedalam tabung reaksi, kemudian ditambahkan $5 \mathrm{~mL}$ ammonia encer dan $5 \mathrm{~mL}$ asam sulfat pekat. Diamati perubahan warnanya. Sampel mengandung flavonoid jika didapatkan perubahan warna menjadi merah atau jingka kekuningan.

Dimasukkan $3 \mathrm{~g}$ ekstrak kedalam tabung reaksi, ditambahkan 10mL CHCl3 0,05N, ditutup aluminium foil dan dikocok perlahan. Didiamkan hingga terbentuk lapisan yang terpisah. Lapisan $\mathrm{CHCl} 3$ diambil dipindahkah ke tabung reaksi lain. Selanjutnya ditambahkan $0,5 \mathrm{~mL} \mathrm{H} 2 \mathrm{SO} 42 \mathrm{~N}$, ditutup aluminium foil dan dikocok perlahan. Kembali didiamkan hingga terbentuk lapisan terpisah. Lapisan H2SO4 dipipet dan dipindahkan ke tabung lain. Pada larutan yang merupakan lapisan dibawahnya ditambahkan satu tetes pereaksi Mayer, Bouchardat dan Dragendorff. Hasil positif 
terdapat alkaloid apabila terbentuk endapan putih untuk pereaksi Mayer, endapan coklat untuk pereaksi Bouchardat dan jingga untuk pereaksi Dragendorff.

Dimasukkan $0,5 \mathrm{~g}$ ekstrak ke dalam tabung reaksi dan ditambahkan ferri klorida $(\mathrm{FeCl} 3) \quad 0,1 \%$ dan diamati terjadinya perubahan warna. Sampel mengandung tanin jika terbentuk warna biru tua atau biru kehitaman.

Dimasukkan $2 \mathrm{~g}$ ekstrak kedalam tabung reaksi dan ditambahkan $2 \mathrm{~mL}$ asam sulfat, kemudian dididihkan dan disaring. Filtrat yang didapat ditambahkan $2 \mathrm{~mL}$ asam asetat anhidrat, lalu diamati perubahan warnanya. Jika warna berubah menjadi biru atau hijau maka steroid positif, jika warna berubah menjadi merah sampai ungu maka triterpenoid positif.

Dimasukkan 0,5g ekstrak ke dalam tabung reaksi, filtrat ditambahkan beberapa tetes ferriklorida $0,1 \%$ dan diamati terjadinya perubahan warna. Positif mengandung senyawa fenolik jika terjadi perubahan warna hitam kebiruan.

Dimasukkan 0,1g ekstrak ke dalam tabung reaski, ditambahkan $10 \mathrm{~mL}$ aquades yang dididihkan, kemudian ditutup dengan aluminium foil, dikocok kuat selama 30 detik hingga terbentuk busa. Diamati kestabilan pembentukan busa. Jika busa bertahan selama 30 menit dengan ketinggian $3 \mathrm{~cm}$ dari cairan maka disebut kandungan saponin positif.

\section{$2.4 \mathrm{Uji} \mathrm{DPPH}$}

Dibuat pengencaran standart dan ekstrak yang digunakan. Ektrak tanaman diencerkan dengan konsentrasi $50 \mu \mathrm{g} / \mathrm{mL}$, $100 \mu \mathrm{g} / \mathrm{mL}, 200 \mu \mathrm{g} / \mathrm{mL}, 400 \mu \mathrm{g} / \mathrm{mL}, 800 \mu \mathrm{g} / \mathrm{mL}$. Sedangkan standart digunakan asam askorbat dengan konsentrasi $8 \mu \mathrm{g} / \mathrm{mL}, \quad 16 \mu \mathrm{g} / \mathrm{mL}, \quad 24 \mu \mathrm{g} / \mathrm{mL}, \quad 32 \mu \mathrm{g} / \mathrm{mL}$, dan $64 \mu \mathrm{g} / \mathrm{mL}$. Diambil masing-masing $1 \mathrm{~mL}$ larutan ekstrak, larutan standart dan larutan blanko (larutan DPPH terdiri dari $2 \mathrm{~mL}$ DPPH $0,1 \mathrm{mM}$ dan $1 \mathrm{~mL}$ metanol) ke dalam tabung reaksi yang berbeda. Ditambahkan kedalam masing-masing tabung reaksi, $2 \mathrm{~mL}$ DPPH 0,1mM. Divorteks dan diinkubasi pada suhu kamar selama 30 menit ditempat gelap. Absorbansi larutan ekstrak dan blanko diukur pada $\lambda$ maks $516 \mathrm{~nm}$, sedangkan asam askorbat pada $\lambda$ maks $515 \mathrm{~nm}$. Pengukuran absorbansi di ulang 3 kali. Data hasil pengukuran absorbansi dianalisa persentase aktivitas antioksidannya menggunakan persamaan berikut:

$$
\% \text { inhibisi }=\frac{\text { Abs blanko }- \text { Abs sampel }}{\text { Abs blanko }} \times 100
$$

\section{Hasil dan Pembahasan}

Penelitian ini bertujuan untuk mengetahui potensi ekstrak daun kesambi sebagai antioksidan. Sebelum diuji antioksidan dengan metode DPPH, dilakukan pembuktian kandungan ekstrak daun kesambi dengan uji reaksi warna. Hasil uji reaksi warna ekstrak daun kesambi dengan pelarut air, metanol dan etanol 96\% dapat dilihat pada Tabel 1-3.

\section{Tabel 1}

Hasil uji reaksi warna ekstrak daun kesambi dengan pelarut air

\begin{tabular}{lll}
\hline \multicolumn{1}{l}{ Identifikasi senyawa } & & Hasil \\
\hline Flavonoid & & + \\
\hline Alkaloid & Meyer & - \\
\hline & Dragendrof & - \\
\hline Tanin & Bouchartdat & - \\
\hline Terpenoid & & + \\
\hline Fenol & Steroid & - \\
\hline Saponin & Triterpenoid & + \\
\hline & & + \\
\hline
\end{tabular}

\section{Tabel 2}

Hasil uji reaksi warna ekstrak daun kesambi dengan pelarut metanol

\begin{tabular}{lll}
\hline Identifikasi senyawa & & Hasil \\
\hline Flavonoid & & + \\
\hline Alkaloid & Meyer & + \\
\hline & Dragendrof & - \\
\hline & Bouchartdat & + \\
\hline Tanin & & + \\
\hline Terpenoid & Steroid & - \\
\hline Fenol & Triterpenoid & + \\
\hline Saponin & & + \\
\hline
\end{tabular}

Tabel 3

Hasil uji reaksi warna ekstrak daun kesambi dengan pelarut etanol $96 \%$

\begin{tabular}{lll}
\hline \multicolumn{1}{l}{ Identifikasi senyawa } & & Hasil \\
\hline Flavonoid & & + \\
\hline Alkaloid & Meyer & - \\
\hline & Dragendrof & - \\
\hline & Bouchartdat & + \\
\hline Tanin & & + \\
\hline Terpenoid & Steroid & - \\
\hline Fenol & Triterpenoid & + \\
\hline Saponin & & + \\
\hline
\end{tabular}

Hasil uji reaksi warna menunjukkan ekstrak daun kesambi dengan pelarut air hanya mampu mengikat 5 senyawa aktif (flavonoid, tanin, triterpenoid, fenol dan saponin), pelarut metanol dan etanol $96 \%$ mampu mengikat 7 senyawa aktif (flavonoid, alkaloid, tanin, triterpenoid, fenol dan saponin). Perbedaan antara ekstrak daun kesambi dengan pelarut metanol dan etanol $96 \%$ adalah uji alkaloid, dimana metanol positif dengan uji regen Meyer dan Bouchartdat, sedangkan etanol $96 \%$ positif hanya pada uji regen Bouchartdat. Secara keseluruhan uji reaksi warna menunjukkan daun kesambi mengandung senyawa metabolit sekunder yang berupa 
flavonoid, alkaloid, tanin, triterpenoid, fenol dan saponin. Hasil penelitian ini tidak jauh berbeda dengan penelitian yang dilakukan oleh Situmeang et. al. yang juga melakukan uji reaksi warna pada ekstrak metanol daun kesambi yang menghasilkan positif pada uji flavonoid, alkaloid, steroid, fenolik dan tanin [17]. Namun hal ini berbeda dengan analisa uji reaksi warna yang dilakukan oleh Soundararajan dan Sivakkumar, dimana ekstrak daun kesambi dengan pelarut air dan etanol memiliki kemampuan yang sama dalam mengikat senyawa metabolit sekunder yang berupa alkaloid, saponin, senyawa fenolik dan tanin, flavonoid dan fitosterol. Analisa fitokimia kuantitatif didapatkan senyawa fenol (71.92 \pm $0.92 \mathrm{mgGAE} / \mathrm{gm})$ dan flavonoid $(9.69 \pm 1.38 \mathrm{mgQE} / \mathrm{gm})$ merupakan senyawa metabolit yang terbanyak jumlahnya didalam ekstrak daun kesambi [10].

Perbedaan pelarut ekstrak daun kesambi mempengaruhi jenis senyawa aktif yang terikat. Senyawa bioaktif lebih efektif diikat oleh pelarut dengan polaritas tinggi [18]. Senyawa polifenol akan optimal jika di ektraksi dengan pelarut polar daripada nonpolar [19]. Wang dan Helliwell melaporkan bahwa pelarut etanol lebih baik untuk mengikat polifenol daripada metanol dan aseton [20]. Tetapi peneliti lain menyarankan bahwa aseton adalah pelarut yang lebih baik untuk ekstraksi polifenol daripada air dan kloroform [21]. Didalam penelitiannya, Qasim, et. al. menyimpulkan bahwa ekstrak metanol $80 \%$ adalah pelarut yang lebih baik untuk ekstraksi polifenol dari tanaman halofit dibandingkan pelarut lainnya (air, etanol 80\%, aseton dan kloroform) [22]. Hasil penelitian Chanda et. al., yang mengekstraksi 12 macam tanaman herbal India dengan pelarut eter, aseton dan metanol, disimpulkan bahwa total kandungan flavonoid lebih tinggi didapatkan pada pelarut metanol, dan sedangkan kandungan fenolik sangat sedikit jumlahnya [23]. Temuan di atas menunjukkan bahwa hasil polifenol dan flavonoid tergantung pada jenis dan polaritas pelarut ekstraksi, di samping karakteristik fisik sampel tanaman [24].

$\mathrm{IC}_{50}$ hasil dari uji aktivitas antioksidan dengan metode DPPH dapat dilihat pada Tabel 4. Nilai $\mathrm{IC}_{50}$ ekstrak daun kesambi dengan pelarut metanol merupakan terendah $(16,12 \mu \mathrm{g} / \mathrm{mL})$ dibandingkan dengan pelarut etanol $96 \%$ $(20,43 \mu \mathrm{g} / \mathrm{mL})$, dan air $(904,28 \mu \mathrm{g} / \mathrm{mL})$. Sedangkan nilai $\mathrm{IC}_{50}$ asam askorbat sebagai standart adalah $7,16 \mu \mathrm{g} / \mathrm{mL}$. Semakin besar nilai $\mathrm{IC}_{50}$, maka aktivitas antioksidan akan semakin lemah, sedangkan semakin kecil nilai $\mathrm{IC}_{50}$, maka aktivitas antioksidan akan semakin besar. Nilai IC $_{50}$ pada tabel menunjukkan bahwa aktivitas antioksidan yang terbaik di antara 3 pelarut ini adalah ekstrak kesambi dengan pelarut metanol. Bahkan nilai $\mathrm{IC}_{50}$ ekstrak daun kesambi dengan pelarut metanol hanya dua kali lipat dari nilai $\mathrm{IC}_{50}$ standart (asam askorbat). Sehingga menggunakan pelarut metanol hasil aktivitas antioksidan ekstrak daun kesambi akan mendekati nilai aktivitas antioksidan asam askorbat. Pada penelitian yang dilakukan oleh Truong et. al., didapatkan ektrak tanaman Severinia buxifolia dengan pelarut metanol memiliki efek antioksidan yang paling tinggi (IC50 $16.99 \mu \mathrm{g} / \mathrm{mL}$ ) dibandingkan dengan pelarut air, etanol, kloroform, diklorometan dan aseton [18].

Nilai IC $_{50}$ ekstrak daun kesambi dengan pelarut air jauh sangat tinggi. Hal ini disebabkan pelarut air hanya mampu mengikat sedikit senyawa metabolit sekunder pada daun kesambi seperti yang ditunjukkan pada hasil uji reaksi warna. Tingginya nilai IC50 ekstrak daun kesambi dengan pelarut air juga dilaporkan oleh penelitian Situmeang et. al. dimana nilai IC50 yang diperoleh sebesar 272,28ppm [17]. Perubahan polaritas pelarut dapat mempengaruhi ekstraksi gugus senyawa antioksidan yang dipilih dan aktivitas antioksidan selanjutnya [25]. Boulekbache-Makhlouf et. al. melaporkan bahwa senyawa golongan fenol dan turunannya (flavonoid dan tanin) merupakan agen pereduksi dan penghambat radikal bebas yang kuat [26]. Berdasarkan hasil penelitian ini, golongan senyawa yang diketahui terkandung dalam ekstrak daun kesambi melalui uji reaksi warna (diantaranya, fenol, flavonoid dan tanin) diduga bertanggung jawab terhadap aktivitas antioksidan ekstrak daun kesambi.

Tabel 4

Nilai $\mathrm{IC}_{50}$ ekstrak daun kesambi pada berbagai pelarut

\begin{tabular}{lcccc}
\hline \multirow{2}{*}{ Pelarut } & \multicolumn{3}{c}{$\mathrm{IC}_{50}(\mu \mathrm{g} / \mathrm{mL})$} & \multirow{2}{*}{ Rerata IC IC $_{50}$} \\
\cline { 2 - 4 } Metanol & Ulangan 1 & Ulangan 2 & Ulangan 3 & 16,12 \\
Etanol 96\% & 15,38 & 17,70 & 15,27 & 20,43 \\
Air & 20,34 & 20,51 & 20,43 & 904,28 \\
Asam Askorbat & 903,89 & 905,29 & 903,67 & 7,16 \\
\hline
\end{tabular}




\section{Kesimpulan}

Berdasarkan hasil uji reaksi warna dan uji aktivitas antioksidan dengan menggunakan metode DPPH disimpulkan bahwa ekstrak daun kesambi memiliki potensi sebagai antioksidan dan besarnya kemampuan antioksidan daun kesambi ditentukan oleh pelarut yang digunakan dalam hal ini pelarut metanol yang paling baik aktivitas antioksidannya. Golongan senyawa yang diduga bertanggungjawab terhadap aktivitas antioksidan ekstrak daun kesambi berdasarkan uji reaksi warna adalah fenol, flavonoid dan tanin.

\section{Ucapan Terimakasih}

Penelitian ini didanai dari Dana Bantuan Penelitian BOPTN 2019 dari Universitas Negeri Maulana Malik Ibrahim Malang.

\section{Daftar Pustaka}

[1] CABI. 2020. Schleichera oleosa (Macassar oil tree). [ONLINE]. Available from : https://www.cabi.org/isc/datasheet/49004\#toidentity [cited 21 may 2020].

[2] Hanum, I. Faridah. 1997. Plant Resources of South-East Asia. [ed.] L.J.G. van der Maesen. Vol. 11. Leiden : Backhuys Publishers.

[3] Suita, Eliya. 2012. Kesambi (Schleichera oleosa MERR. Bogor: Balai Penelitian Teknologi Perbenihan Tanaman Hutan

[4] Silitonga, A., Masjuki, H., Mahlia, T., Onga, H. C., Kusumo, F., Aditiya, H., \& Ghazalia, N. Schleichera oleosa $L$ oil as feedstock for biodiesel production. Fuel. 2015;156:63-70.

[5] Thind, T. S., Singh, R., Kaur, R., Rampal, G., \& Arora, S. In vitro antiradical properties and total phenolic contents in methanol extract/fractions from bark of Schleichera oleosa (Lour.) Oken. Medicinal Chemistry Research. 2011;20:254260.

[6] Srinivas, K., \& Baboo, R. C. GC-MS Study of Schleichera oleosa (Lour.) Oken. IJCPR, 2011;2(2):106-109.

[7] Goswami, S., Singh, R. P., \& Gilhotra, R. The effect of isolated quercetin of the leaf extract of Schleichera oleosa (lour) oken on Ascardia galli. International Journal of Pharmaceutical Research. 2020;12(2):544-554.

[8] Thatavong, X. 2015. Chemical Constituents And Biologycal Activities From Crude Hexane Extract Of Schleichera oleosa Fruits. [MD thesis]. Burapha : Burapha University.

[9] Tiwari, N., \& Pandey, V. Qualitative and Quantitave Phytochemical Screening of Secondary Metabolites in Seeds of Schleichera Oleosa (Lour.). IJSRSET. 2017;3(6):357-359.

[10] Soundararajan, M., \& Sivakkumar, T. Pharmacognostical investigation, phytochemical studies of Schleichera oleosa (lour) oken leaves. Int. J. Res. Pharm. Sci. 2017;8(2):109-119.

[11] Wojdyło, A., Oszmiański, J., \& Czemerys, R. Antioxidant activity of phenolic compounds in 32 selected herbs. Food Chemistry. 2001;105(3):940-949.
[12] Panche, A., Diwan, A., \& Chandra, S. Flavonoids: an overview. J Nutr Sci. 2016;5(e47):1-15.

[13] Altemimi, A., Lakhssassi, N., Baharlouei, A., Watson, D., \& Lightfoot, D. Phytochemicals : Exctraction, Isolation, and Identification of Bioactive Compounds from Plant Extracts. Plants. 2017;6(42):56-72.

[14] Hutzler, P., Fischbach, R., Heller, W., Jungblut, T., Reuber, S., Schmitz, R., . . . Schnitzler, J.-P. Tissue localization of phenolic compounds in plants by confocal laser scanning microscopy. Journal of Experimental Botany. 1998;49(323):953-965.

[15] Ghisalberti, E. 2008. Detection and Isolation of Bioactive Natural Products. In S. Colegate, \& R. Molyneux. Bioactive Natural Products : detection, Isolation and Structural Determination. Boca Raton: CRC Press.

[16] Harris, D. 2010. Quantitative Chemical Analysis. New York: W. H. Freeman and Company.

[17] Situmeang, B., Nuraeni, W., Ibrahim, A. M., \& Silaban, S. Analysis of secondary metabolite compounds from leaves extract kesambi (Schleichera oleosa) and antioxidant activity test. Jurnal Pendidikan Kimia. 2016;8(3):164-168.

[18] Truong, D.-H., Nguyen, D. H., Ta, N. T., Bui, A. V., Do, T. H., \& Nguyen, H. C. Evaluation of the Use of Different Solvents for Phytochemical Constituents, Antioxidants, and In Vitro Anti-Inflammatory Activities of Severinia buxifolia. Journal of Food Quality. 2019;ID 8178294:1-9.

[19] Liu, X., Dong, M., Chen, X., Jiang, M., Lv, X., \& Yan, G. Antioxidant activity and phenolics of an endophytic Xylaria sp. from Ginkgo biloba. Food Chemistry. 2007;105(2):548-554.

[20] Wang, H., \& Helliwell, K. Determination of flavonols in green and black tea leaves and green tea infusion by highperformance liquid chromatography. Food Research International. 2001;34(2-3):223-227.

[21] Hayouni, E., Abderrabba, M., Bouix, M., \& Hamdi, M. The effect of solvents and extraction method on the phenolic contents and biological activities in vitro of Tunisian Quercus coccifera L. and Juniperus phoenicea L. fruit extracts. Food Chemistry. 2007;105(3):1126-1134.

[22] Qasim, M., Aziz, I., Rasheed, M., Gul, B., \& Khan, M. Effect of extraction solvents on polyphenols and antioxidant activity of medicinal halophytes. Pak. J. Bot. 2016;48(2):621-627.

[23] Chanda, S., Bhayani , D., \& Desai, D. Polyphenols and Flavonoids of Tweleve Indian Medicinal. The Bioscan. 2013;8(2):595-601.

[24] Buhmann, A., \& Papenbrock, J. An economic point of view of secondary compounds in halophytes. Functional Plant Biology. 2013;40:952-967.

[25] Razali, N., Mat-Junit, S., Abdul-Muthalib, A., Subramaniam, S., \& Abdul-Aziz, A. Effects of various solvents on the extraction of antioxidant phenolics from the leaves, seeds, veins and skins of Tamarindus indica L. Food Chemistry. 2012;131(2):441-448.

[26] Boulekbache-Makhlouf, L., Medouni, L., Medouni, S., Arkoub, L., \& Madani, K. Effect of solvents extraction on phenolic content and antioxidant activity of the byproduct of eggplant. Industrial Crops and Products. 2013;49:668-674. 